J.W. Allen:

Louise Mackie:

D. James:

E. Atil:

I. Lapidus:

O. Grabar:
"Shaban, Barquq, and the Decline of the Mamluk Metalworking Industry"

"Mamluk Textiles: National and International Considerations"

"The Koran of Baybars I"

"Mamluk Painting in the Late 15 th Century"

"The Political, Economic and Social Setting"

"Architecture and the Arts"

\title{
FUTURE CONFERENCES
}

\section{Symposium: To Commemorate the Ataturk Centennial University of Chicago - 1981}

The Middle East Center of the University of Chicago will sponsor a one-day symposium on the above. Details will be announced later.

$$
\frac{\text { 2nd International Turkish Folklore Congress }}{\text { Bursa, Turkey-June 22-28, } 1987}
$$

For details, write: Kültür Bakanlığı, Millî Folklor Araştırma Dairesi, 11. Milletlerarası Türk Folklor Kongresi, Hazırlık Komitesi Başkanlığı, Mithatpaşa Cad., Ak Han, No. 33, Kat 6; Yenişehir, Ankara, Turkey.

\section{1st International Congress on History of Turkish-Islamic Science and Technology Istanbul Technical University - Sept. 14-18, 1981}

For more details, write: Ms. Zeynep Kınık, Bilim ve Teknoloji Tarihi Enstitüsü, ITÜ Taşkışla Oda 219, Istanbul, Turkey.

\section{5th Naval History Symposium U.S. Naval Academy - October 1-2, 1981}

The History Department of the U.S. Naval Academy will sponsor its fifth symposium on naval history. The symposium will welcome suggestions for papers on all topics relating to naval history. For information, write: Frederick S. Harrod, History Department, U.S. Naval Academy, Annapolis, MD 21402.

\section{NEWS OF OTHER ASSOCIATIONS AND ANNOUNCEMENTS}

\section{American Institute of Iranian Studies}

The Institute remained open in Tehran through the Revolution, but has been effectively closed since the autumn of 1979. During the period of December 4-6, 1980, the Institute's library and furnishings were confiscated and removed from the premises of the Center in Tehran by representatives of the Bonyad-e Mostaz afin. The Institute has protested this confiscation to representatives of the Bonyad-e Mostaz afin in New York, to Iran's representatives to the United Nations, and to the Ambassador of Algeria in Washington, D.C. The Institute remains active in this country. For further information, contact: Brian Spooner, Secretary, AlIS, 325 University Museum/F-1, University of Pennsylvania, Philadelphia, PA 19104.

\section{Middle East Outreach Council}

[Summary of Report following MEOC's Wingspread Conference, held at Johnson Foundation in Racine, WI, February 27 to March 1, 1981.] 